\title{
Micronutrients and Diazotrophs Affecting Maize Plant Growth in Alluvial and Calcareous Soils
}

\author{
H.M. El-Zemrany ${ }^{*}$, M.M. El-Shinnawi and Naglaa E.A. \\ El-Noamany \\ Dept. Soil Sci., Fac. Agric., Minufiya Univ., Shibin El-Kom, \\ Egypt
}

\begin{abstract}
A greenhouse pot experiment was carried out to investigate the influence of a combination among a mixture of 3 micronutrients $(\mathrm{Mn}, \mathrm{Zn}$ and $\mathrm{Cu})$ added as sulphate salts and two diazotrophic bacteria (Free-living Azotobacter + associative Azospirillum) on maize (Zea mays L.) plants. Six treatments of the micronutrients mixture and bacteria with six replicates were applied to each of two soils (alluvial clay and calcareous sandy). Treated plants were collected at 30 and 45 days after sowing. Fresh and dry weights and nutrient contents of maize plants were determined. The obtained results proved the enhancing influence of the different treatments on the fresh and dry matters of the plants. Likewise, the concentration and uptake of $\mathrm{N}, \mathrm{P}$, $\mathrm{K}, \mathrm{Mn}, \mathrm{Zn}$ and $\mathrm{Cu}$ of the plant shoots, were augmented by all treatments applied at the two periods of growth. On the other hand, all the assessed parameters of the plants grown on the alluvial soil excelled those on the calcareous one
\end{abstract}

Keywords: Diazotrophic bacteria, Nutrients, Clay soil, Calcareous soil, Zea mays

Micronutrients are of vital roles in cereal crop production, especially in less fertile soils. Among the micronutrients, having important nutritional and physiological functions in plants and microorganisms, are manganese, zinc and copper. Such micronutrients are of significantly direct and indirect actions on plant growth and crop yield, as well as on the vitality of beneficial soil microorganisms, again in favour of the growing plants (Marschner, 1998, Zeiger \& Taiz, 2010 and Poole, 2013).

On the other hand, nitrogen is one of the most limiting nutrients required for growing plants. Organic nitrogen is the major part of such element in soil, but not too much is known about the chemistry, microbiology and cycling of such organic form, especially when there is a large input of $\mathrm{N}$ biologically from the air (Wild and Russell, 1988). Some plants can absorb simple organic N compounds, i.e. amino acids, but the relative importance of this source in different habitats is not known. Addition of nitrogen to soil as fertilizer and through biological fixation (diazotrophy) is a standard practice in agriculture (Vessey, 2003).

*Corresponding author: Tel.01008177332 Fax. 202/ 25769495

E.mail: hamdy_elzemrany@yahoo.fr 
Application of mineral $\mathrm{N}$ fertilizers has increased in the world agriculture, but too much of such nitrogen form can lead to a terrestrial and aquatic pollution and needs to be reduced (Mengel et al., 2001). Biofertilizers are alternatives as to increase soil productivity and improve plant growth in a sustainable agriculture regime. Biological nitrogen fixation (BNF) is the most important biochemical reaction for life on earth (Bohlool et al., 1992).

Greater cultivation of cereals brings forth higher production cost and pollutes the soil environment, due to excessive use of chemical fertilizers. Therefore, biofertilizers has been considered as alternative sources for reducing the environmental pollution. In the biofertilizer technology, Rhizobium-legume symbiosis is most common process and widely used in different countries. During the last three decades, it has been also found that certain diazotrophs $\left(\mathrm{N}_{2}\right.$ - fixers) can make an association with graminaceous plants such as rice, wheat, maize, barley and other cereals, as endophytic interrelationship, without forming any nodule-like structure or causing any disease symptoms. Recent findings showed better plant growth and higher crop yield of cereals both quantitatively and qualitatively, due to biofertilizers application. In addition, accumulation of plant nutrients, other than $\mathrm{N}$, like $\mathrm{P}, \mathrm{K}, \mathrm{Ca}, \mathrm{Mg}$ and even Fe has been also observed. Further research in this area had been reported by Döbereiner et al. (1993) and Jensen \& Nielsen (2003).

Based upon the importance of micronutrients and biological dinitrogen fixation to soil fertility and sustainable agriculture, the present investigation aims at studying the efficiency of $\mathrm{N}_{2}$-fixing bacterial agents (diazotrophs) with mixtures of certain essential micronutrients, on plant growth of maize (Zea mays) grown oneach of two different soils, namely alluvial and calcareous.

\section{Materials and Methods}

A greenhouse pot experiment was carried out at the experimental farm of the Faculty of Agriculture, Minufiya University, Egypt, to investigate the efficiency of biological nitrogen fixation (diazotrophy), a mixture of 3 micronutrients ( $\mathrm{Mn}$, $\mathrm{Zn}$ and $\mathrm{Cu}$ ) and their combinations on the growth and elemental contents of Maize (Zea mays) plants grown on each of two different soils. Each plastic pot of $30 \mathrm{~cm}$ diameter and $25 \mathrm{~cm}$ depth was filled with $5 \mathrm{~kg}$ soils (alluvial clay soils from the experimental farm of the Faculty of Agriculture, Minufiya University and calcareous soil of EL- Nobariya, Egypt). Physical and chemical properties of the used soils and their contents of some nutrients were determined according to Page et al. (1982) and Klute (1986), and data are recorded in Table 1.

The experimental design was a randomized block, with six replicates. The potted soils were exposed to the treatments presented in Table 2. All pots received super phosphate $\left(15.5 \% \mathrm{P}_{2} \mathrm{O}_{5}\right)$ at a rate of $200 \mathrm{~kg} \mathrm{fed}^{-1}$. (19 pots). The diazotrophic bacterial co-inocula used were those of Azotobacter "B1" and Azospirillum "B2" (2.3 x $10^{7} \mathrm{cfu}$ each). B1 was applied to the maize seeds in a powder form mixed with Arabic gum, while B2 was added to the soil as a liquid. The seed inoculation was introduced directly before sowing.

Egypt. J. Soil Sci. 56, No. 4 (2016) 
MICRONUTRIENTS AND DIAZOTROPHS AFFECTING MAIZE PLANT... 685

TABLE 1. Initial physical and chemical properties and nutrient contents of the tested alluvial and calcareous soils

\begin{tabular}{|c|c|c|c|}
\hline Properties & Units & Alluvial soil & Calcareous soil \\
\hline Particle size distribution: & $\%$ & & \\
\hline Sand & & 34.7 & 79.7 \\
\hline Silt & & 23.6 & 10.2 \\
\hline Clay & & 41.7 & 10.1 \\
\hline Textural grade & & Clay loam & Sandy \\
\hline Organic matter & $\%$ & 1.9 & 0.6 \\
\hline $\begin{array}{l}\mathrm{pH}, 1: 2.5 \text { (soil/ water) } \\
\text { suspension }\end{array}$ & & 7.2 & 8.2 \\
\hline $\begin{array}{l}\text { E.C, 1:5(soil:water) } \\
\text { extract(TSS) }\end{array}$ & $\mathrm{dSm}^{-1}$ & 0.6 & 1.1 \\
\hline \multicolumn{4}{|l|}{ Soluble cations: } \\
\hline $\mathrm{Na}^{+}$ & \multirow{4}{*}{ meq $/ 100 \mathrm{~g}$} & 1.4 & 3.2 \\
\hline $\mathrm{K}^{+}$ & & 0.2 & 0.5 \\
\hline $\mathrm{Ca}^{++}$ & & 0.9 & 1.2 \\
\hline $\mathrm{Mg}^{++}$ & & 0.5 & 0.6 \\
\hline \multicolumn{4}{|l|}{ Soluble anions: } \\
\hline $\mathrm{Cl}^{-}$ & \multirow{4}{*}{ meq $/ 100 \mathrm{~g}$} & 1.8 & 4.1 \\
\hline $\mathrm{HCO}_{3}^{-}$ & & 0.4 & 0.7 \\
\hline $\mathrm{CO}_{3}^{--}$ & & 0.0 & 0.0 \\
\hline $\mathrm{SO}_{4}^{--}$ & & 0.8 & 0.7 \\
\hline Total $\mathrm{CaCO}_{3}$ & $\%$ & 2.9 & 15.7 \\
\hline Total N & \multirow{3}{*}{$\%$} & 0.15 & 0.06 \\
\hline Total P & & 0.10 & 0.05 \\
\hline Total K & & 0.60 & 0.08 \\
\hline Available N & \multirow{3}{*}{$\mathrm{mg} / \mathrm{kg}$} & 58.11 & 14.00 \\
\hline Available P & & 9.20 & 1.57 \\
\hline Available K & & 270.00 & 60.10 \\
\hline Total Mn & \multirow{3}{*}{$\mathrm{mg} / \mathrm{kg}$} & 134.00 & 68.00 \\
\hline Total Zn & & 37.00 & 29.00 \\
\hline Total $\mathrm{Cu}$ & & 89.00 & 58.00 \\
\hline \multicolumn{4}{|l|}{ DTPA extractable : } \\
\hline $\mathrm{Mn}$ & \multirow{3}{*}{$\mathrm{mg} / \mathrm{kg}$} & 9.20 & 3.10 \\
\hline $\mathrm{Zn}$ & & 7.50 & 2.10 \\
\hline $\mathrm{Cu}$ & & 4.20 & 0.70 \\
\hline
\end{tabular}

Egypt. J. Soil Sci. 56, No. 4 (2016) 
TABLE 2. The experimental treatments for either soil planted with maize.

\begin{tabular}{|c|c|c|c|c|c|}
\hline \multirow{3}{*}{$\begin{array}{c}\text { Treatment } \\
\text { No. }\end{array}$} & \multicolumn{4}{|c|}{ Micronutrients mixtures } & \multirow{3}{*}{$\begin{array}{c}\text { Bacterial } \\
\text { Inoculation"B" } \\
(\text { Exp. } \\
\text { Simpols**) }\end{array}$} \\
\hline & \multirow{2}{*}{$\begin{array}{c}\text { Mixtures"M" } \\
(\text { Exp. } \\
\text { Simpols*) }\end{array}$} & $\mathrm{Mn}$ & $\mathrm{Zn}$ & $\mathrm{Cu}$ & \\
\hline & & \multicolumn{3}{|c|}{$\begin{array}{c}\text { Concentration of each } \\
\text { element } \\
\text { in the mixtures ( } \mathrm{mg} / \mathrm{kg} \text { soil })\end{array}$} & \\
\hline $1 \mathrm{a}$ & \multirow{2}{*}{ M0 } & \multirow{2}{*}{0} & \multirow{2}{*}{0} & \multirow{2}{*}{0} & B0 \\
\hline $1 \mathrm{~b}$ & & & & & $\mathrm{~B} 1+\mathrm{B} 2$ \\
\hline $2 a$ & \multirow{2}{*}{ M1 } & \multirow{2}{*}{100} & \multirow{2}{*}{10} & \multirow{2}{*}{15} & B0 \\
\hline $2 b$ & & & & & $\mathrm{~B} 1+\mathrm{B} 2$ \\
\hline $3 a$ & \multirow{2}{*}{ M2 } & \multirow{2}{*}{200} & \multirow{2}{*}{50} & \multirow{2}{*}{25} & B0 \\
\hline $3 b$ & & & & & $\mathrm{~B} 1+\mathrm{B} 2$ \\
\hline
\end{tabular}

* M0 = Control (no addition), M1 = Lower rate, M2 = Higher rate of micronutrients.

$* * \mathrm{~B} 0=$ Control (uninoculated), $\mathrm{B} 1=$ Azotobacter, $\mathrm{B} 2=$ Azospirillum.

Each pot was planted with seven grains of maize (Zea mays, c.v. T.W. c. 321). Moisture content of the potted soils was kept constantly at $60 \%$ of the water holding capacity (WHC) of each soil, via every 3 day- compensation using tap water. After 10 days of sowing, seedlings of each pot were thinned to 4 plants. All pots were supplied with potassium sulphate $\left(48 \% \mathrm{~K}_{2} \mathrm{O}\right)$ at a rate of $100 \mathrm{~kg} / \mathrm{fed}$. $(0.5 \mathrm{~g} / \mathrm{pot})$ and ammonium nitrate $(33 \% \mathrm{~N})$, at a rate of $150 \mathrm{~kg} / \mathrm{fed} .(0.75 \mathrm{~g} /$ pot).Worth mentioning that, the calcareous soil received 1.5 times of the NPK fertilizer amounts as much as those applied to the alluvial soil. The assigned micronutrient mixtures (M1\&M2) were added as $\mathrm{MnSO}_{4}, \mathrm{ZnSO}_{4} \cdot 7 \mathrm{H}_{2} \mathrm{O}$ and $\mathrm{CuSO}_{4}$, potassium sulphate and ammonium nitrate were applied together with irrigation water. After 30 days of sowing, whole plants of three replicates were randomly uprooted (the first sampling), washed well and carefully with tap water to remove the soil particles away from the plant roots and again washed with distilled water. The plant roots were then separated from the shoots, and each were weighed to record the fresh weight. Roots and shoots were then oven-dried at $70{ }^{\circ} \mathrm{C}$ for $48 \mathrm{hrs}$, to get the dry weight, and the data were later statistically analyzed, as "LSD" (Gomez and Gomez, 1984). Samples of the dried plant shoots were finely ground and kept for chemical analysis. Plants of other three replicates were taken off the pots after 45 days of sowing (the second sampling) and subjected to the same measurements. $0.2 \mathrm{~g}$ of the dried fine materials of maize shoots were digested with a mixture of $10 \mathrm{ml}$ concentrated $\mathrm{H}_{2} \mathrm{SO}_{4}$ and $\mathrm{HClO}_{4}$ (at a ratio $3: 1)$. The contents of $\mathrm{N}, \mathrm{P} \& \mathrm{~K}(\%)$ and $\mathrm{Mn}, \mathrm{Zn} \& \mathrm{Cu}(\mathrm{ppm})$ in the diluted digest were determined according to Cottenie et al. (1982).

\section{Results and Discussion}

Fresh and dry matter yields of the plants

Data presented in Tables $3 \& 4$ indicate that, the fresh and dry matter yields of maize plants exhibited wide variations among the treatments undertaken for the alluvial clay loam and calcareous sandy soils examined, at both sampling periods Egypt. J. Soil Sci. 56, No. 4 (2016) 
(30 \& 45 days after sowing). The lowest values of fresh and dry weights of the plant roots and shoots, and subsequently of the whole plants, were found for those untreated with both micronutrients "M0" and diazotrophs"B0" ( the double controls "M0 B0"). Application of either level of the micronutrients mixture, without bacterial inocula (B0), declared significant increases in the weights of both organs of maize plants grown on the two soils, with the alluvial giving higher values than the calcareous one. Such increases were promoted by elevating the level of micronutrients addition (M2>M1). The effect of those elements was a result of their distinguish roles in the metabolic processes and enzyme activities within plant tissues at the different growth stages (Alloway, 2008). Results gained for the dry matter yield of each organ, for the co-treatment "B1 + B2" of each major treatment "M1/M2", were higher at the latter sampling time than at the earlier one (Tables $3 \& 4$ ). This was attributed to accumulation of plant materials by advancing the growth period. Micronutrients addition revealed higher increases in the fresh and dry weights of plant shoots, as compared with those of roots. Such trend was expressed by the calculated values of the relative changes "RC" referring to the double controls treatment (M0 B0).

This was observed, for both soils at either sampling time, between the co treatments "B1 + B2" for each major treatment "M1/M2" (Tables 3 \& 4). These results are explained by presence of most metabolic processes in the plant leaves (Marschner, 1998 and Alloway, 2008).

At the same addition level of micronutrients composite, the weights (fresh and dry) obtained for both roots and shoots of the maize plants grown on the alluvial soil, excelled those of the calcareous soil (Tables $3 \& 4$ ). Accordingly, values of "RC" of the plants grown on the first soil were greater than those of the other soil. This finding denotes that, the alluvial soil responded to the micronutrients fertilization much more than the calcareous soil. Physical and chemical properties of the tested soils (Table 1) were the reason of such result. For instance, the high values of $\mathrm{CaCO}_{3}$ and $\mathrm{pH}$ of the calcareous soil diminished the availability of the supplying micronutrients. On the other hand, the higher content of each of the fine mineral fraction (clay + silt) and organic matter in the alluvial soil contributed to a more availability and absorption of those micronutrients (Abou Hussien et al., 2002).

Application of the bi - inoculant of both bacterial diazotrophs together, i.e. the free-living Azotobacter"B1"+ the associative Azospirillum "B2", as biofertilizers, resulted in highly influence on fresh and dry matter mass of both roots and shoots of the maize plants grown on either soil, at the two growth intervals, compared to the single control treatment (uninoculated) "B0"(Tables $3 \& 4)$. Hence, all values of the "RC" for both fresh and dry weights of roots and shoots were positive. This finding points out that, the diazotroph inoculants, via their role in atmospheric nitrogen fixation, had direct and indirect stimulatory effects as biofertilizers on the plant growth in general (Pandy \& Kumar, 1989 and Kirchhof et al., 1997). 


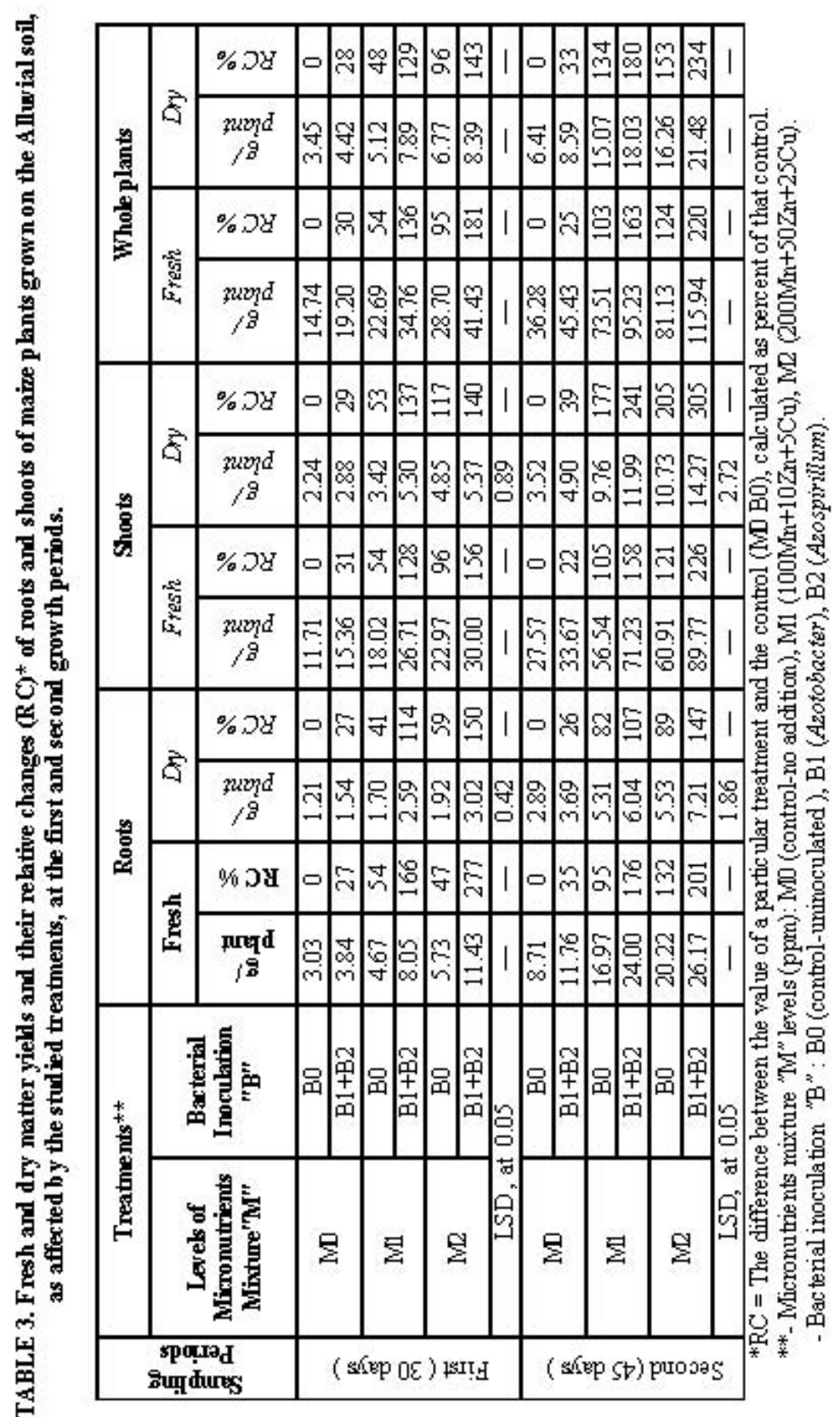




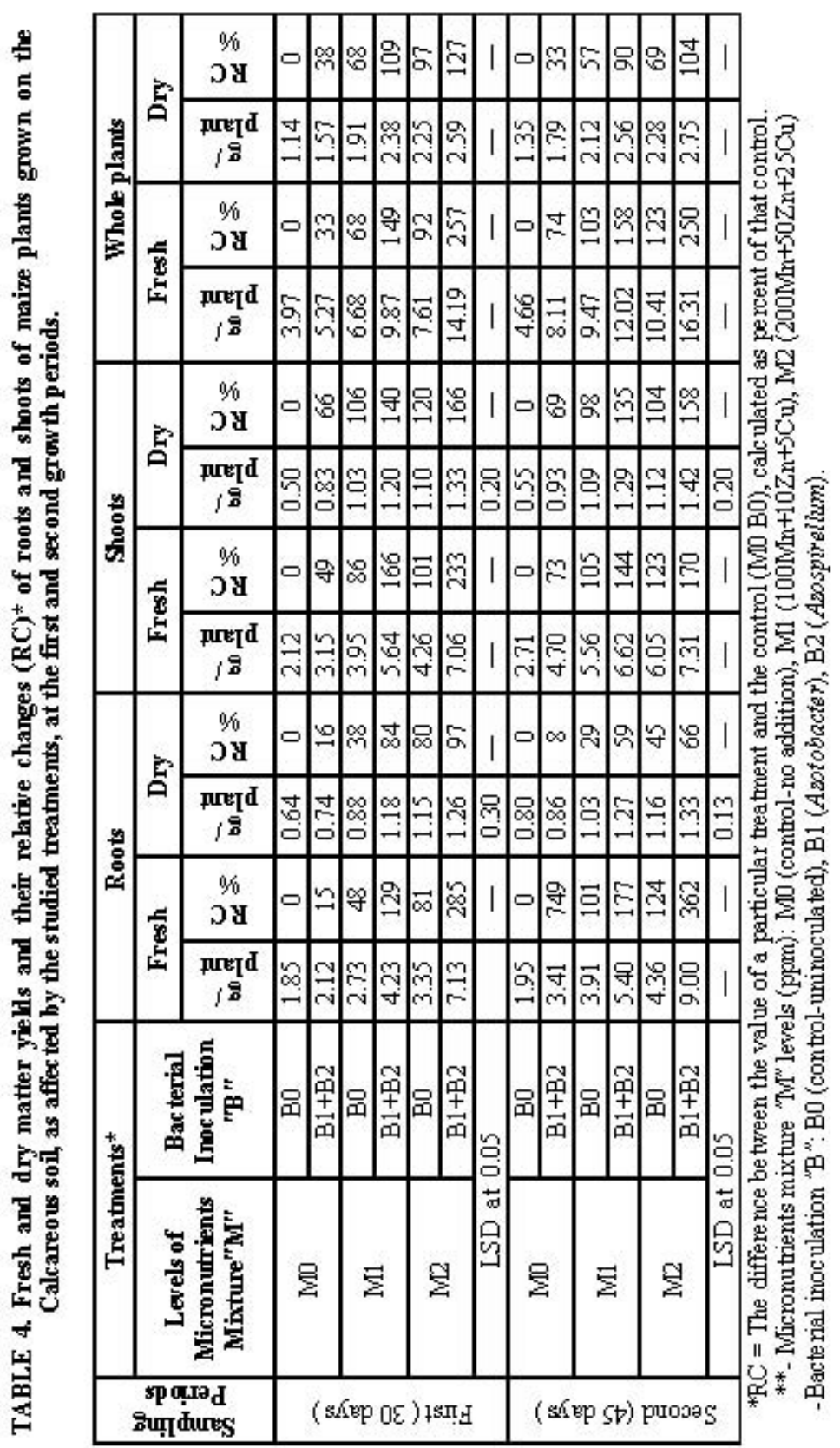


Inoculation with the bacterial free -living and associative $\mathrm{N}_{2}$ - fixers $(\mathrm{B} 1+\mathrm{B} 2)$ showed varying "RC" values of the roots and shoots of maize plants, among the different experimental treatments (Tables 3\&4). Moreover, presence of such dinitrogen fixing-agents activates the biochemical processes in the rhizosphere, which is, in turn developed the plant growth (Dogan et al., 2010).The indirect beneficial effect of bacterial inoculation on soil conditions favorably suited the plant growth in both soils, with the alluvial surpassing the calcareous (Lapinskas, 1998 and Oliveira et al., 2004).

On comparing between the micronutrient and bacterial treatments, as to affect the maize plant growth, data presented in Tables $3 \& 4$ demonstrate, for the two cultivated soils and at both growth periods, that the growing plants exhibited positive responses to the diazotrophs inoculation more than those of the micronutrient amendments. These findings were supported by the "RC" values of plant roots and shoots fresh and dry weights for both the major and co-treatments $(\mathrm{M} \& \mathrm{~B})$.

Consequently, the data in Tables $(3 \& 4)$ show that, combination between each of the treatments of micronutrient composites and dual bacterial inoculation ("M1 /M2" plus "B1 + B2") gave the uppermost growth rates of maize plants appearing in both soils examined, at the two sampling times. This response varied between the plant organs depending on growth stage, as well as from one soil to another. For example, the shoot weights increased at higher extents than those of the roots, at both growth stages. This is due to the expansion of the above-ground green parts of the plants through elapsing the time during which active photosynthesis and $\mathrm{N}_{2}$-fixation, being involved in anabolic processes, and thus directly participate in building up the vegetative mass. Nevertheless, the "RC" values generally indicated the superiority of root responses above those of the shoots at the earlier sampling time, but an opposite trend was observed at the second sampling. The poor physical, chemical and biological properties of the calcareous soil made it inferior in the experimental measurements. Moreover, the low fertility (nutritional status) of the calcareous soil induced a declination of the plant growth rate particularly at the latter stage (Table 4). These results are in agreement with the reports of Mc Laughlin and Smolders (2001) and Alloway (2008), confirming the necessity of micronutrients application to soil to ameliorate the microbial activity and plant growth.

Figures gained for the fresh and dry weights of the maize plant organs revealed that, the highest differences between both measurements were recorded for the treatment of higher level of micronutrients mixture (M2) together with the dual diazotroph co-inoculum. This means that such combined treatments encouraged the translocation of nutrients from soil up into the growing plant shoots. Ratios between the dry to the fresh weights of roots were slightly higher than those of the shoots, i.e. approximately 15-33\% for roots and 15-25\% for shoots, of the plants grown on either soil (Tables $3 \& 4)$. Those ranges depended on soil conditions, treatment applied and growth stage of the plants. This might be interpretted by the relatively higher existence of sap in the above-ground

Egypt. J. Soil Sci. 56, No. 4 (2016) 
green parts of the plants. It was generally detected that, the separate treatments with the diazotrophs augmented the absorption of soil solution more than those with the micronutrients composite. Intensity of the biological processes, namely photosynthesis and $\mathrm{N}_{2}$-fixation, were obviously behind such varying outcomes.

\section{Macronutrient contents in the plant shoots}

Data listed in Tables 5\&6 display that the concentrations and uptake of NPK in the shoots of maize plants grown on the alluvial and calcareous soils tested, at the two growth periods increased with adding either level of the micronutrients composite without or with bacterial inoculation. The lower level "M1" exhibited relatively higher results than the higher one "M2". This was due to a role of the added micronutrients composite, at an appropriate level, in encouraging the plant growth via enhancing the rate of metabolic processes, whilst the higher level might cause some chemical and biochemical complications in soil and plants (Marschner, 1998). Values of the rate of change "RC" calculated for the concentrations of N, P and K taken up by the maize plants, grown on both soils, were positive, but at variable extents depending on soil properties and the nutrient determined. For instance, the "RC" values of phosphorus was the highest and followed descendingly by nitrogen and potassium, at both growth periods, with the earlier one being lower than the latter. Despite the mostly constant "RC" values of $\mathrm{K}$, its concentrations and uptake values were changeable, being correlated with the changes in the dry mass of shoots. Likewise, the alluvial soil excelled the calcareous one in such concern. These findings are in harmony with the reports of Mengel et al. (2001), Farooq et al. (2012) and Keram et al. (2012).

In regard to the impact of the dinitrogen-fixing bacterial inoculation, apart from the micronutrients addition, on $\mathrm{N}, \mathrm{P} \& \mathrm{~K}$ concentrations and uptake by the maize plants, data appearing in Tables $5 \& 6$ reveal that, there were evident increases in the contents of the assessed macronutrients in the maize shoots, being higher for the alluvial soil and at both sampling times than those for the calcareous soil. This was an output of incorporating the $\mathrm{N}_{2}$-fixers. Elevating the dose of the micronutrients mixture augmented the values obtained for the macronutrients concerned, but the higher level "M2" again declined the extents of increment.

Application of the asymbiotic and associative diazotrophs certainly brought about increasing the content of nitrogen in maize shoots, being derived from the atmosphere via plant roots (El-Howeity et al., 2003). This $\mathrm{N}_{2}$-fixing process stimulates the other biological activities, leading to accumulation of various nutrients. Introduction of the appropriate level of the micronutrients mixture together with the diazotrophs inoculation gave higher contents of the nutrients determined in the plants (Weisany et al., 2013).

\section{Micronutrient contents in the plant shoots}

Data recorded in Tables $7 \& 8$ manifest that concentrations and uptake of the micronutrients, $\mathrm{Mn}, \mathrm{Zn}$ and $\mathrm{Cu}$, and $\mathrm{RC}$ in the shoots of maize plants, slightly 
increased by the applications of micronutrients mixture and diazotrophs inoculation, at the two vegetative growth periods. This augmentation was in a positive correlation with the level added of such particular treatment (M2>M1). This was true and verified by the "RC" values for both soils, with the alluvial excelling the calcareous, at either sampling time. These findings are in agreement with the notes of Das et al. (2005) and Alloway (2008).

$\mathrm{Zn}$ exhibited the highest response, then $\mathrm{Cu}$ and $\mathrm{Mn}$ came descendingly, as indicated by the "RC" calculations, with the alluvial soil having higher percentages than those for the calcareous one.

The combined treatments of both micronutrients mixture (with its two levels of addition)and the dual diazotroph inoculant, applied to both soils, achieved higher increases in the contents of $\mathrm{Mn}, \mathrm{Zn}$ and $\mathrm{Cu}$, as compared with each separate experimental treatment. So, better positive values of the "RC", of the micronutrients concentration in the shoot tissues, were gained.

Such values were greater for the alluvial soil than those for the calcareous one, and thus for the second sampling than for the first one (Tables $7 \& 8$ ).

Noteworthy that, the "RC" values calculated for the first sampling time were mostly higher for all of the experimental measurements, than those at the second time, being referred to the hastened absorption rate of nutrients early to push up the plant growth.

Table (1) appeared the superiority of alluvial soil on the calcareous one from the standard point of the physical, chemical and biological characteristics. Such properties of the alluvial soil make it a good medium for the activity of microorganisms and growth of plants. However, the some parameters make the calcareous soil a poor one (Wild and Russell, 1988; Eleiwa et al., 2012 and Bajgiran, 2013).

The present study indicated the importance of applying the selected micronutrients, $\mathrm{Mn}, \mathrm{Zn}$ and $\mathrm{Cu}$ at their assigned levels, within the permissible range (AOAC, 1995), as nutritional enrichments for, the soils cultivated with maize, to enhance, not only the plant growth, but also the vitality and activity of the inoculating non-symbiotic free - living Azotobacter and the associative endophyte Azospirillum, as wellas the other rhizobacteria. Such treatments suited a vigorous plant growth and its elemental take up, via dinitrogen fixation, production of metabolic regulators and improving nutrients absorption in general (Frankenberger and Arshad, 1995; Vessey, 2003 and Weisany et al., 2013).

Egypt. J. Soil Sci. 56, No. 4 (2016) 
MICRONUTRIENTS AND DIAZOTROPHS AFFECTING MAIZE PLANT..

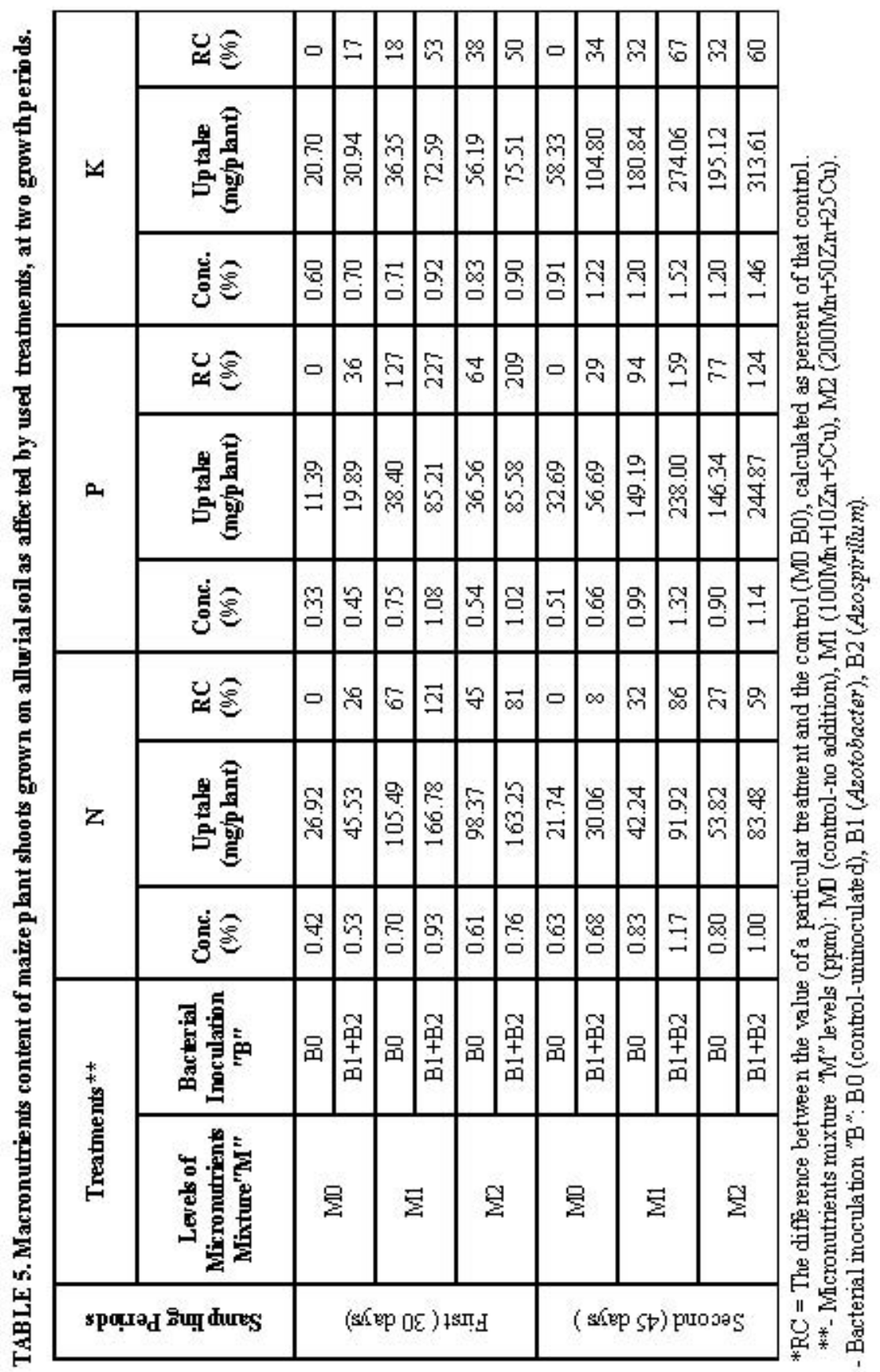




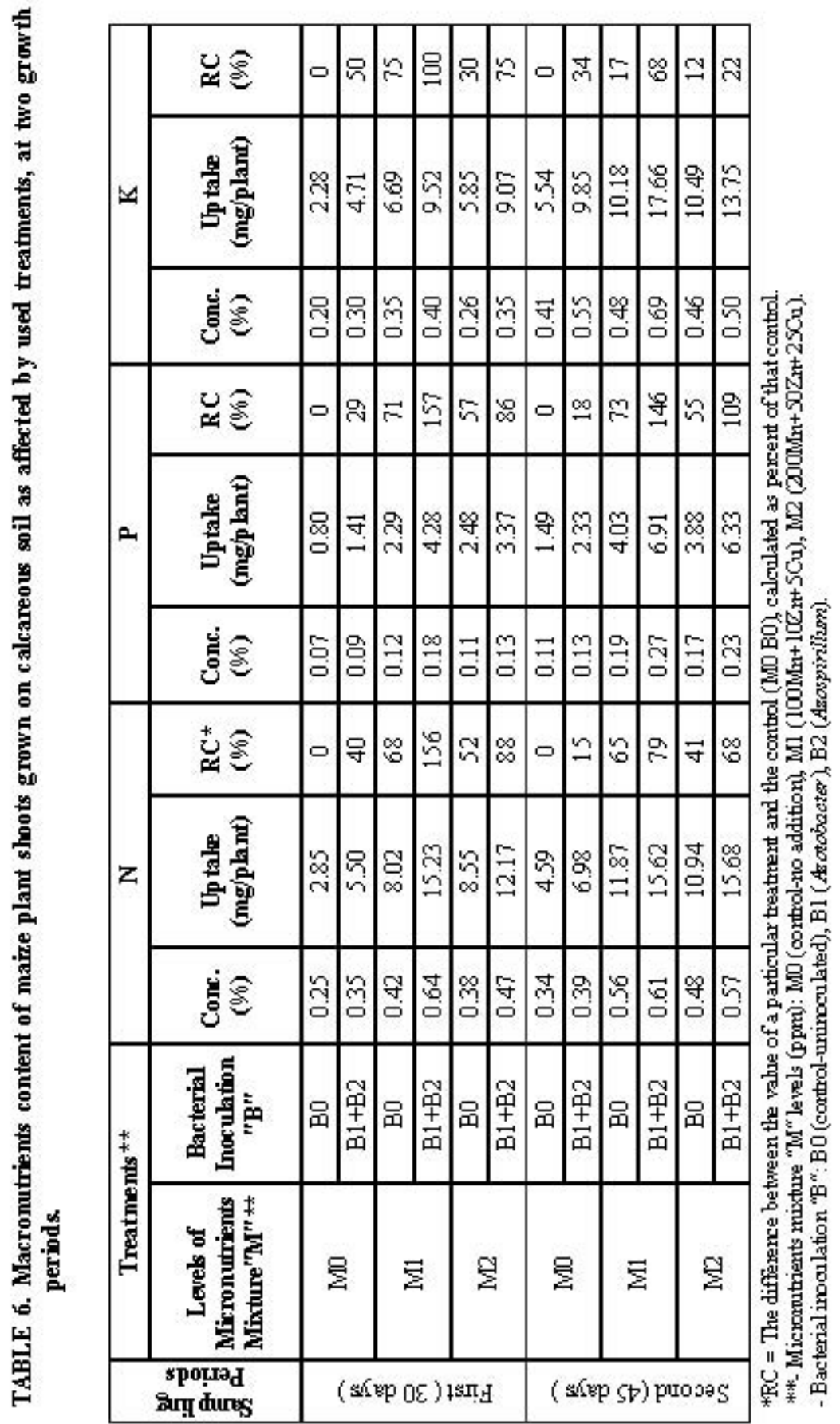




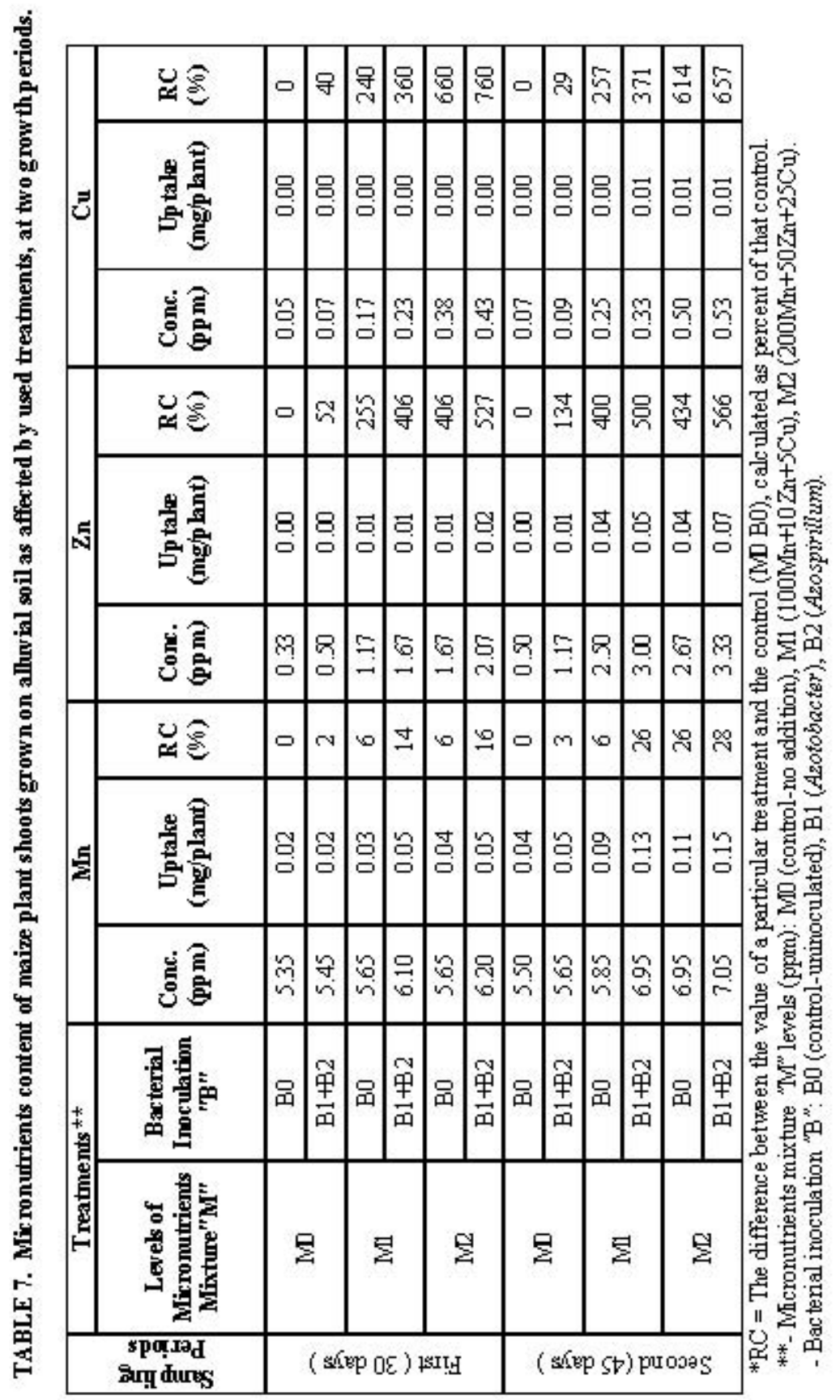




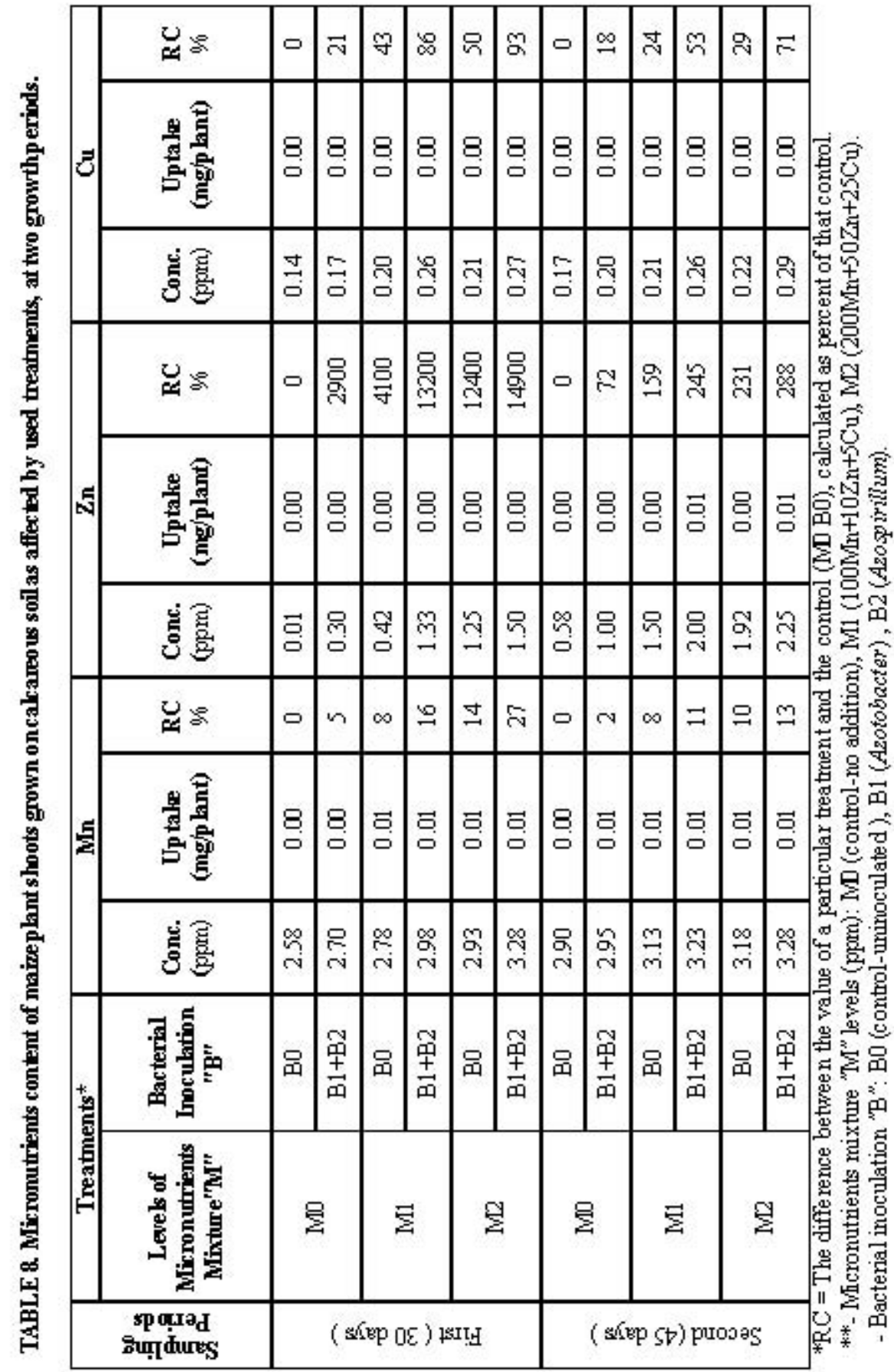




\section{References}

Abou-Hussien, E. A. and Barsoum, Sanna W. (2002) The combined effect of salinity and nitrogen fertilization on calcareous soil properties and oil crops growth. Zagazig . J. Agric . Res., 29(1), 151-167.

Alloway, B.J. (2008) Copper and zinc in soils: Too little or too much? In NZ Trace Elements Group Conference.Waikato University, Hamilton, 13 - 15.

AOAC. (1995) Official Methods of Analysis. Association of Official Analytical Chemists. Washington D.C., USA.

Bajgiran, A.R. (2013) Influence of soil amendments and soil properties on macro - and micronutrients availability to microorganisms and plants. Ph.D.Thesis, Swedish univ. Agric. Sci. Upsala, Sweden.

Bohlool, B.B., Ladha, J.K., Garrity, D.P. and George, T. (1992) Biological nitrogen fixation for sustainable agriculture: A perspective. Plant and Soil, 141, 1-11.

Cottenie, A., Verloo, M., Kikens, L., Velghe, G. and Camerlynck, R. (1982) Analytical Problems and Methods in Chemical Plant and Soil Analysis. Hand book ( Ed.A. Cottenie). Gent, Belgium.

Das, K., Dang, R., Shivananda, T.N. and Sur, P. (2005) Interaction effect between phosphorus and zinc on their availability in soil in relation to their contents in stevia (Stevia rebaudiana).Research article. World Journal, 5, 490-495.

Döbereiner, J., Reis, V. M., Paula, M. A. and Olivares, F. L. (1993). Endophyticdiazotrophs in sugar cane, cereals and tuber plants. In: Palacios R, Mora $\mathrm{J}$ and Newton WE (Ed.), New horizons in nitrogen fixation. Current Plant Sci. Biotech. Agric., 17, 671-676.

Dogan, K., Gok, M. and Coskan, A. (2010) Effects of bacteria inoculation and iron application on biomass, yield and nitrogen contents in Cukurova region. 5th National Plant Nutri. Fertil. Congress. Izmir, Turky.

Eleiwa, Mona E., Hamed, Eman R. and Shehata, Heba (2012) The role of biofertilizers and/or some micronutrients on wheat plant (TriticumaestivumL.) growth in newly reclaimed soil. J. Medicinal Plants Res., 6(17), 3359-3369.

El-Howeity, M., Omar, M., El-Shinnawi, M. and Aboel-Naga, S. (2003) Colonization Pattern of some diazotrophs on wheat (Triticum aestivum) and maize (Zea mays) roots in vitro and in vivo experiments. 11 th Conf. Microbial. Proc., Cairo, Egypt: $81-90$.

Farooq, M., Wahid, A. and Siddique, K. (2012) Micronutrients application through seed treatments . a review. J. Soil Sci. Plant Nutri., 12(1), 125-142.

Frankenberger, W.T.jr. and Arshad, M. (1995) Phytohormones in Soil : Microbial Production and Function. Marcel Dekker Inc. NY, USA. 
Gomez,A. and Gomez, A.A.(1984) Statistical Methods of Agricultural Research. John Wiley \& Sons pub, New York, USA.

Jensen, E.S. and Nielsen, H. H. (2003) How can increased use of biological nitrogen fixation in agriculture benefit the environment? Plant and Soil, 252, 177-186.

Keram, K. S., Sharma, B. L. and Sawarkar, S. D. (2012) Impact of Zn application on yield, quality, nutrients uptake and soil fertility in a medium deep black soil (Vertisol). Inter. Sci. Environ. Tech., 1 (5), 563 - 571.

Kirchhof, G., Schloter, M., Assmus, B. and Hartmann, A. (1997) Molecular microbial ecology approaches applied to diazotrophs associated with non-legumes. Soil Biol. Bioch ., 29, 853-862.

Klute, A. (1986) Methods of Soil Analysis, Part 2:Physical and Mineralogical Properties. Amer. Soc. Agron. Inc. Madison, Wise., USA.

Lapinskas, E. (1998) Biologinio azoto fiksavimasir nitraginas. Akademija, 218: monografija. - Dotnuva-Akademija: LŽI, 218 p.

Marschner, H. (1998) Mineral Nutrition of Higher Plants. Harcourt Brace \& Co. Pub. London, New York, Tokyo.

McLaughlin, M.J. and Smolders, E. (2001) Background zinc concentrations in soil affecting the zinc sensitivity of soil microbial processes-a rationale for a metalloregion. approach to risk assessments. Environ. Toxi. Chem., 20, 2639-2643.

Mengel, K., Kosegarten, H. and Appel, T. (2001) Principles of Plant Nutrition. Kluwer. Acad. Pub; Dordrecht. The Netherlands.

Oliveira, A. L.M., Canuto, E. L., Silva, E. E., Reis, V. M. and Baldani, J. I. (2004) Survival of endophytic diazotrophic bacteria in soil under different moisture levels. Brazil. J. Microbiol., 35, 295-299.

Page, A.L., Miller R.H. and Keeney, D.R. (1982) Methods of Soil Analysis. Part 2: Chemical and Microbiological properties., Amer. Soc. Agron. Madison, Wis. USA.

Pandy, A. and Kumar, S. (1989) Potential of Azotobacters and Azospirilla as biofertilizers for upland agriculture. A review. J. Sci. and Industrial Res., 48(3), 134-144.

Poole, R. K. (2013) Advances in Microbial Physiology. Elsevier Sci. Pub. Amest., The Nethelands.

Vessey, J. K. (2003) Plant growth promoting rhizosphere as biofertilisers. Plant and Soil, 255, 571- 586.

Weisany, W., Raei, Y. and Allahverdipoor, K. (2013) Role of some of mineral nutrients in biological nitrogen fixation. Bull. Environ. Pharm. Life Sci., 2 (4), 77 - 84.

Wild, A. and Russell, E.W. (1988) Russell's Soil Conditions and Plant Growth. Harlow Longman. London, UK.

Egypt. J. Soil Sci. 56, No. 4 (2016) 
Zeiger, E. and Taiz, L. (2010) Plant Physiology. Sinauer Associates, CA. USA.

(Received: $11 / 3 / 2014$

Accepted: 12 / 2 /2017)

\section{المغذيات الصغرى ومثبتات النيتروجين الجوى وتأثير هم على نمو نباتات الذرة في أراضى رسوبية واتئية وجيرية}

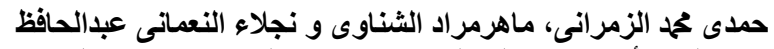

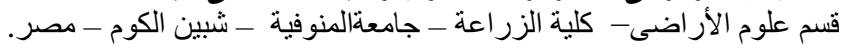

أجريت تجربة أصص بالصوبة المفتوحة لدراسة تأثير مخلوط من المغذيات

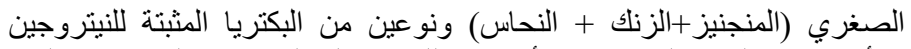

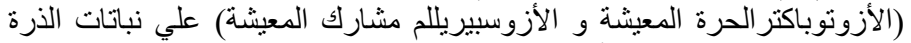

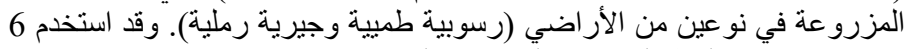

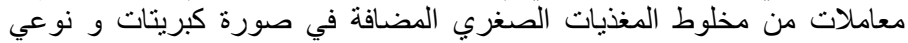

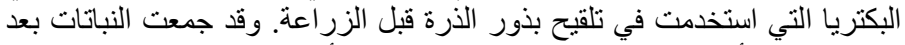

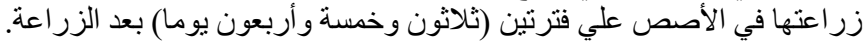

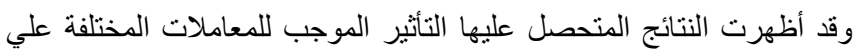

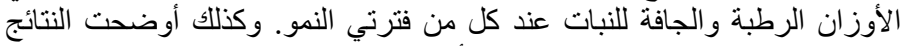

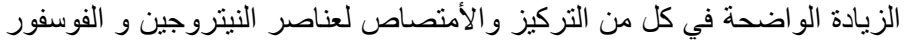

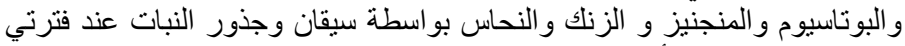

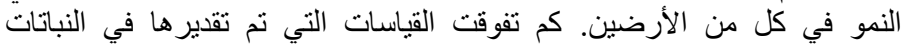
المزروعة في الأرض الطينية علي مثنلاتها في الأرض الجيرية. 
